\title{
RELATED FACTORS OF CARPAL TUNNEL SYNDROME (CTS) AMONG ONION SKIN PEELER WORKER AT SEGIRI SAMARINDA, EAST KALIMANTAN
}

\author{
Dina Lusiana Setyowati, Dyah Dwijayanti, Muhamad Sultan \\ Departement of Occupational Health and Safety, Faculty of Public Health, Mulawarman \\ University \\ Email: dina_setyowati@yahoo.com
}

\begin{abstract}
Background: Various activities that involve hands repetitively are often associated with Carpal Tunnel Syndrome (CTS). CTS is defined by compression of the median nerve in the wrist. Peeling onion skin is a risk job which can be easily affected by CTS. To determine the relationship between repetitive motions, duration of work, work of service, the history of IIIness and CTS among onion skin peeler workers at Segiri Market Samarinda.

Method: This research used a cross-sectional design to analyze the relationship among the variables. The subject of this study were people who work as peel onion in the Segiri Market Samarinda and the sampling method of this research using purposive sampling with 31 participants. Data was analysed using Chi-Square by SPSS 16 Program with significance level of $0.05(5 \%)$.

Results: The results showed that there was a correlation between repetitive motions ( $p=$ $0.008)$, duration of work $(p=0.000)$, work of service $(p=0.034)$ and CTS; and there was no relationship between history of IIIness and CTS $(p=1.000)$.

Conclusion: The conclusion of the research that there was a relationship between repetitive motions, duration of work, work of service and Carpal Tunnel Syndrome (CTS); and there was no relationship between history of Illness and Carpal Tunnel Syndrome (CTS).
\end{abstract}

Keywords: CTS, Duration of Work, Work of service, History of Disease, Repetitive Movement

\section{Introduction}

Industrial development in Indonesia has been currently increased very rapidly, both formal and informal industries. Informal sector is one of the businesses that have a very high health risk. Unfortunately, in general the business sector has not been touched yet by the employer to their employees. ${ }^{1}$ Various activities that are using hand repetitively for a long time often associated with the occurrence of Carpal Tunnel Syndrome (CTS). Carpal Tunnel Syndrome (CTS) a manifestation of median nerve compression within the carpal tunnel of wrist due to increased intra-tunnel pressure from a variety of source. ${ }^{2}$ Tana research reported that cases of work-related CTS is one of Cumulative Trauma Disorders of the fastest lead in effect of abnormalities to workers. This can result in losses due to decreased of productivity, increased of medical expenses and increased of compensation due to the limitations and disability workers. The pain of CTS varies from feeling a little uncomfortable until the conditions are not able to do the work by hands. ${ }^{3}$

Repetitive motion is one of the risk factors that causes Carpal Tunnel Syndrome (CTS). It will increase the pressure on the carpal tunnel that would cause damage which may be the cause of compression on the nerves and cause CTS. ${ }^{4}$ Duration of action is also one of the risk factors that can lead to Carpal Tunnel Syndrome (CTS). Harsono reported that there was an increase of working period with Carpal Tunnel Syndrome (CTS) to workers due to the repetitive finger movements continuously for 
long periods of time, causing stress to the tissue around the carpal tunnel. ${ }^{5}$ It has been reported that CTS is associated with certain diseases and condition such as diabetes, hypothyroidism, pregnancy, rheumatoid arthritis, and work related factor. ${ }^{6}$

Onion skin stripping business in Samarinda Segiri market environment is an informal sector enterprises in the form of services. Result of a preliminary survey indicates that the onion skin peeler has been exposed to a risk factors Carpal Tunnel Syndrome (CTS), which are due to a repetitive movement, duration of work, work of service and also a history of the disease. Therefore, we conducted this study to determine the relationship between repetitive movements, duration of work, work of service and history of the disease on the incidence of Carpal Tunnel Syndrome (CTS) toward the onion skin peeler at Segiri Market Samarinda.

\section{Research Method}

This research is analytical survey with cross sectional study design. Samples were onion peeler in Samarinda Segiri market with 31 persons as a purposive sampling. Carpal tunnel syndrome (CTS) is defined as a compression of the median nerve in the wrist. It is the commonest of the compressive syndromes and the most frequent cause is idiopathic. Even though spontaneous regression is possible, the general rule is that the symptoms will be worse. The diagnosis is primarily clinical, from the symptoms and provocative tests. Data were analyzed using chi square statistical test with $\alpha=(0.05), \mathrm{Cl} 95 \%$.

\section{Results and Analysis}

\section{A. Characteristics of Respondent}

Table 1 shows information on the age group and education level. The subject in the present study $(n=31)$ were onion peeler in Samarinda Segiri Market. The percentage of respondent was CTS 34-39 year were $75.0 \%$. Most of respondents $65.4 \%$ were basic education level was CTS.

Table 1. Characteristic of Respondent

\begin{tabular}{ccccc}
\hline \multirow{2}{*}{ Variable } & \multicolumn{4}{c}{ CTS } \\
\cline { 2 - 5 } Age & Yes & No & $\%$ \\
\hline $16-21$ & 2 & 66.7 & 1 & 33.3 \\
$22-27$ & 2 & 40.0 & 3 & 60.0 \\
$28-33$ & 7 & 63.6 & 4 & 36.4 \\
34-39 & 9 & 75.0 & 3 & 25.0 \\
Education Level & & & & \\
$\quad$ Basic & 17 & 65.4 & 9 & 34.6 \\
Midlle & 3 & 60.0 & 2 & 40.0 \\
\hline
\end{tabular}

Data analysis was performed using the Statistical Package for Social Sciences (SPSS) version 16.00. The relationship between repetitive movement, work of service, duration of work, history of illness and Carpal Tunnel Syndrome (CTS) among onion skin peeler worker Segiri Market in Samarinda showed in Table 2. 
Table 2. Relationship between Repetitive Movements, Work of Service, Duration of Work, History of Illness and Carpal Tunnel Syndrome (CTS) Among Onion Skin Peeler Worker Segiri Market In Samarinda

\begin{tabular}{|c|c|c|c|c|c|}
\hline \multirow{2}{*}{ Factors } & \multicolumn{4}{|c|}{ CTS } & \multirow[b]{2}{*}{$\mathbf{p}$} \\
\hline & Yes (n) & $\%$ & No $(n)$ & $\%$ & \\
\hline \multicolumn{6}{|l|}{ Repetitive Movement } \\
\hline Risk (> 30/min) & 12 & 92.3 & 1 & 7.7 & 0.008 \\
\hline No Risk (<30/min) & 8 & 44.4 & 10 & 55.6 & \\
\hline \multicolumn{6}{|l|}{ Work of Service } \\
\hline$>5$ Year & 13 & 86.7 & 2 & 133 & 0.034 \\
\hline$<5$ Year & 7 & 43.8 & 9 & 56.3 & \\
\hline \multicolumn{6}{|l|}{ Duration of Work } \\
\hline 2 Hour & 9 & 100 & 0 & 0 & 0.000 \\
\hline $1-2$ Hour & 10 & 76.9 & 3 & 23.1 & \\
\hline$<1$ Hour & 1 & 11.1 & 8 & 88.9 & \\
\hline \multicolumn{6}{|l|}{ History of Illness } \\
\hline Yes & 2 & 66.7 & 1 & 33.3 & 1.000 \\
\hline No & 18 & 64.3 & 10 & 35.7 & \\
\hline
\end{tabular}

\section{B. Relationship between Repetitive Movement and Carpal Tunnel Syndrome (CTS) among Peeler Onion in Market Segiri Samarinda}

In this study, Carpal Tunnel Syndrome is diagnosed using Phalen Test. And for the measurement of repetitive movements performed by recording the respondents while peeling onions for a minute and then counted the number of repetitive movements performed while peeling onions. Based on the research that there is a relationship between repetitive movement and Carpal Tunnel Syndrome $(p=0.008)$ in workers onion peeler in Samarinda Segiri Market. The results are consistent with the results of Kurniawan research ${ }^{4}$ on women in rural Karangcengis picker jasmine, Purbalingga also shows the same result that there is a relationship between repetitive movement and CTS with $p$ value $=0.0013$.

Based on Table 1, it's showed that the number of respondents who perform repetitive movement at risk or more than 30 times per minute and experience Carpal Tunnel Syndrome is 12 respondents (92.3\%). While, the respondents who did not at risk when doing repetitive movement or less than 30 times per minute and also had Carpal Tunnel Syndrome is 8 respondents $(44.4 \%)$. Based on the results of this study, 13 respondents with repetitive movement at risk or more than 30 times per minute is 12 respondents $(92.3 \%)$ experience Carpal Tunnel Syndrome. 12 respondents may experience Carpal Tunnel Syndrome because according Bridger ${ }^{7}$ repeated activity, rapid movement can stimulate nerve pain receptors. Complaints of muscle occurs because the muscles receive pressure from a continuous workload without gain an opportunity for relaxation. Arm and hand movements that move repeatedly, especially when the work has a high risk of harm tend to experience CTDs most. The level of risk will increase if the work is done with great power, in a very fast and less recovery time. In addition, an increase in the repetition of the same movements every day would increase the risk for the occurrence of tendinitis. This damage may be the cause of compression on the nerve and cause of CTS. Kurniawan in the study also states that the repetitive movement will increase the pressure on the carpal tunnel. Emphasis on carpal tunnel would cause either reversible or irreversible damage. Increasing the intensity and duration, will reduce blood flow in peripheral blood vessels. In the long term will affect the flow of blood capillary circulation and ultimately have an impact on the permeability of blood vessels at wrist. ${ }^{4}$ According to Suherman ${ }^{5}$ age is one of the risks linked to the incidence of CTS, it is because the older person decreases synovial fluid that can cause swelling in 
the joints. Patients with CTS usually occurs at age 30-60 years. The increasing age will occur degeneration of the bones and this situation will occur at the age of 30 years where there is degeneration in the form of tissue damage, replacement tissue into scar tissue, reducing fluid and this makes stability in the bones and muscles to be reduced. Based on Maghsoudipour study that high speed manual work, age is significant factor associated with CTS. ${ }^{8}$

Posture (shoulder, arm and wrist) association with CTS. ${ }^{9}$ Wrist posture when working peeling onions and onion peeling technique is also one of the factors the occurrence of Carpal Tunnel Syndrome. Our wrist posture observations from video showed that each respondent had peeling techniques are varied. In addition, the position of the hands when peeling was different. Techniques and hand positions while peeling effect on the pressure and the load on the wrist while peeling. For example, the movement of the excess energy will be more at risk for CTS due to pressure on the wrist will cause stress on wrist carpal tunnel area. The rest of 10 respondents (55.6\%) are not at risk and do not experience Carpal Tunnel Syndrome because they did not do a repetitive movement so as not to experience the CTS. And the research shows that majority of respondents have a short duration of less than one hour, in which respondents took time to rest the hand is less than one hour. So with a short duration of action could prevent stress on the median nerve at the wrist.

\section{Relationship between Duration of Work and Carpal Tunnel Syndrome (CTS) among Onion Skin Peeler Workerin SegiriSamarinda Market}

A long duration of action (hour) of the respondents to conduct peeling the onion peel within a day. Duration data obtained from interviews of respondents to the questionnaire respondents. Based on the results that there is a relationship between duration of work and Carpal Tunnel Syndrome in workers onion peeler in Samarinda city Segiri Market $(p=0.000)$. These results are not in line with the research Kurniawan ${ }^{4}$ on the picker jasmine, and also research $\operatorname{Tana}^{10}$ in which the garment workers according to their results no relationship between the duration of work and the Carpal Tunnel Syndrome.

The survey results revealed that the majority of the 31 respondents work more than 8 hours per day. And from 9 respondents who have a long duration of action of more than 2 hours, all the respondents as many as 9 people (100\%) experienced CTS, and for the duration of the 13 respondents who currently works that is $1-2$ hours, there were 10 respondents $(76.9 \%)$ who experienced CTS and 3 respondents $(23.1 \%)$ who did not have CTS. As for the short duration of action that is less than 1 hour, there is one respondent (11.1\%) who experienced CTS and 8 respondents (88.9\%) who did not have CTS. For a longer duration of action of more than 2 hours, all respondents as many as 9 people (100\%) had complaints of CTS. This can be caused by the length of exposure to risk factors, one of which is a repetitive motion that carried the respondents while working. According Kurniawan, ${ }^{4}$, the longer the duration and period of work will increasingly long repetitive movements performed and will reduce blood flow in peripheral blood vessels. In the long term will affect the flow of blood capillary circulation and ultimately have an impact on the permeability of blood vessels at wrist. Factors other respondent characteristics such as age are also influential because of old age and the duration of work, while taking the activity with long working can increase the risk for experiencing CTS. Economic factors could also influence, as more and more onions are peeled then the respondent will also benefit in the form of wages or paid more. So that many of the respondents who prefer to continue working rather than taking to rest their hands.

A total of 10 respondents with a duration of action are moderate to

KESMAS Vol. 9, No. 2, September 2015: 125-132 
experience the CTS that can be due to other factors such as the length of work more than 8 hours, working time more than 5 years of age and who are at risk for CTS. Ergonomic factors such as repetitive movements performed, peeling techniques, hand and finger positions while peeling, position hold of a knife or cutter may be another contributing factor for repetitive movements performed at increased risk for the occurrence of tendinitis. This damage may be the cause compression of the nerve and cause on CTS. The position of the hand when holding also influential for good grip position should be channeled through the grip strength in the muscle between the base of the thumb and little finger, not only at the center of the palms Tana. ${ }^{3}$ And can be seen from the position of holding the respondents still many who do not fit or are not ergonomically designed so it can be a risk of the appearance of the CTS.

A total of 3 respondents and duration of action are not experiencing CTS due to 3 respondents did not perform repetitive movements that these respondents did not experience CTS because it is not exposed to risk factors that repetitive motion. For 8 people who have a short duration and are not experiencing CTS can be caused due to the short duration of action, or less than one hour. Suma'mur ${ }^{11}$ revealed that the duration relates to the physical state of the worker's body. According to Grandjean ${ }^{12}$, the effects of repetitive motion is highly dependent on its old. Prolonged exposure to workers is determined by the length of employment of the workers themselves. Due to the length of work during which workers are exposed by the indicator cause CTS. Therefore, because of the short duration of the respondents exposed by short repetitive motion so that the respondents did not experience CTS. In addition, 8 respondents could rest his hand so there is no pressure on the wrist of the respondents. Respondents short duration of action that is less than one hour and experienced CTS can caused by ergonomic factors that repetitive movements performed at risk or more than 30 times per minute where it is known that the repetition of the same movements every day will increase the risk for the occurrence of tendinitis. This damage may be the cause of the nerve and cause compression on CTS. Addition of video while peeling onions, it can be seen that the respondent is peeling onions with a quick movement and powerful it can also cause respondents experienced CTS. Arm and hand movements are done repeatedly, especially when the work has a high risk of harm to the occurrence of CTDs.the level of repetition, duration of exertion and spent time in forceful exertion reveal significant risk for CTS. ${ }^{9}$

\section{Relationship Work of Service with Carpal Tunnel Syndrome (CTS) among Peeler Onion in Segiri Market Samarinda}

Work of service is the time the respondent worked as onion peeler until the interview process. The work of service data obtained from interviews of respondents to the questionnaire respondents. Based on the results $p$ value $=$ 0.034 , meaning that there is a relationship between the work of service and Carpal Tunnel Syndrome in workers onion peeler in Samarinda Segiri market in 2014. This research according to research conducted by Armstrong ${ }^{13}$, that there is a relationship between the period of employment with Carpal Tunnel Syndrome incident with $p$ value $<0.05$. Additionally Wahyudi ${ }^{14}$ argued in his research on the mat workers get the $p$ value rushes in 0046, this suggests that the period of employment associated with the incidence of CTS. The results of this study are not consistent with research Rogier ${ }^{15}$, which mentions no time employment relationship with the incidence of carpal tunnel syndrome.

Results of the study showed that 15 respondents who are at risk, that his work of service of more than 5 years were 13 respondents $(86.7 \%)$ had given 
complaints of Carpal Tunnel Syndrome. This could be due to work related to the length of time of exposure to repetitive motion carried. The risk of repetitive motion that risk is more than 30 times per minute in long periods of time can cause stress to the tissue around the carpal tunnel so that the tissue degeneration and cause carpal tunnel into a narrow channel. The majority of respondents who have a long working life also have a lifespan of 30-60 years who are at risk, that age was a risk factor will CTS experienced. A total of two respondents (13.3\%) did not experience complaints Carpal Tunnel Syndrome can be because they have been skilled in working peeling onions, other than that of the interview questionnaire is known that the duration of the respondents are moderately long rest periods. In addition, one respondent claimed medicinal drugs often stiff and painful joints. 16 respondents who are not at risk or the work of service of less than 5 years, a total of 7 respondents (43.6\%) had Carpal Tunnel Syndrome, this can be due to ergonomic factors such as the risk of repetitive motion, hand position and grip position besides onion peeling technique. In addition to ergonomic factors can also affect the age, length of employment, duration of work and rest was also able to influence the respondents exposed to Carpal Tunnel Syndrome. A total of 9 respondents $(56.3 \%)$ had no complaints Carpal Tunnel Syndrome can be due to the lack of experience so that they are not skilled in the work that led to the respondents in the works so slow repetitive movements performed were not at risk of developing CTS.

\section{E. Relationship between History Diseases with Carpal Tunnel Syndrome (CTS) among Peeler Onion in Market SegiriSamarinda}

In this study, a history of the disease is a disease history various respondents who could be a trigger factor and supporting the emergence of Carpal Tunnel Syndrome (CTS). Based on the results of the statistical test using Chi Square test $(\alpha)$ obtained $p$ value $=1.000$. This means that there is no relationship between history and Carpal Tunnel Syndrome in workers onion peeler in Samarinda Segiri market in 2014. Based on the analysis shows that of the three respondents had a history of diseases associated with CTS, as many as 2 respondents (6.5\%) had Carpal Tunnel Syndrome. One person experiencing obesity, one person suffered Arthriris Rheumatoid or joint inflammation, and both are equally the same respondents with diabetes mellitus. Disease can be a factor that led to the emergence of Carpal Tunnel Syndrome. As many as one respondent (3.2\%) had no complaints Carpal Tunnel Syndrome. Type a history of disease experienced by respondents is the existence of injury or fracture on the right hand index finger jar. Although never had a broken bone, but the respondents did not feel any complaints CTS. It can be caused at work peeling onions respondents use more than the left hand with his right hand.28 respondents who had no history of diseases associated with CTS, a total of 18 respondents $(58.1 \%)$ had Carpal Tunnel Syndrome. And as many as 10 respondents (32.3\%) did not experience Carpal Tunnel Syndrome. This can be caused by other factors discussed above as repetitive movements done at work, duration of employment, length of employment, length of employment, employment history and other work that is being undertaken. So should the respondent despite having no history of diseases associated with CTS also pay more attention to other risk factors in the work.

In our study we could not find the association between history of the diseases and CTS that is the same with the to research conducted by Kurniawan ${ }^{4}$ on women pickers jasmine where his research showed no correlation between the health of the CTS ( $p$ value $=0.083$ ). And also the study of 
maghsoudipour that could not find significant association between hormonal diseases, rheumatologic and CTS incidence. ${ }^{8}$

\section{Conclusion}

Based on the results of the study the relationship between repetitive movements, duration of work, work of service and history of the disease on the incidence of Carpal Tunnel Syndrome (CTS) on onion skin peeler in Samarinda Segiri Market we concluded that, there is relationship between repetitive movement $(p=$ $0.008)$, Duration of work $(p=0.000)$, work of service $(p=0.034)$ and Carpal Tunnel Syndrome (CTS). There no relationship between History Disease and Carpal Tunnel Syndrome (CTS) among onion skinner $(p=1.000)$.

Advice that can be given is expected that the respondents, especially for respondents who had complaints of Carpal Tunnel Syndrome (CTS) can control the repetitive motion / repetitive at work is at least less than 30 times per minute by using a knife or cutter sharper. So that the skin can be directly peeled onion with 1 movement alone and reduce the burden on the wrist and hand. The respondents should be at work using a special personal protective equipment made of elastic rubber and given a bearing on the wrist area, in order to support and restrict the movement of the wrist. And it is expected to the respondents to always rested his hands for at least 4-5 minutes every hour to reduce the risk of CTS and before work and at rest, stretching on hand to reduce pressure on the median nerve at the wrist while working.

\section{References}

1. Effedi, Fikri, Ergonomi bagi pekerja sektor informal, Jakarta, Cermin Dunia Kedokteran, 2009.

2. Gelberman R. H., Hergenroeder P. T., Hargens A. R., Lundorg G. N., Akeson W. H., The Carpal Tunnel Syndrome. A study of Carpal canal pressures, J Bone Joint Surg Am, $\mathrm{vol} / \mathrm{no}:$ 63(3), pp. 380-3, 1981.

3. Tana, Lusianawaty, Sindrom terowoga karpal pada pekerja, pecegahaan dan pengobatan, Jurnal Kedokteran Trisakti, Jakarta, 2003.

4. Bina Kurniawan, dkk., Faktor risiko kejadian Carpal Tunnel Sindrome (CTS) pada pekerja wanita pemetik melati di Desa Karangkecis, Purbalingga, Jurnal Promosi Kesehatan, vol. 3, Semarang, 2008.

5. Suherman B., Beberapa faktor yang berhubungan dengan Carpal Tunnel Syndrome (CTS) Pada Petugas Rental Komputer di Kelurahan Kauripan Tasikmalaya, Fakultas IImu Kesehatan Universitas Siliwangi, 2012.

6. Spinner R. J., Bachman J. W., Amadio P. C., The many faces of Carpal Tunnel Syndrome, Mayo Clin Proc, vol/no: 64(3), pp. 829-36, 1989.

7. Bridger, R. S., Introduction to Ergonomics, International Editions, General Engineering Series, McGraw-Hill Inc, 1995.

8. Maryam Maghsoudipour, Sasan Maghimi, Faize Deghaan, Azar Rahimpanah, Association of Occupational and Non Occupational Risk Factors with the Prevalance of Work Related Carpal Tunnel Syndrome, J Occup Rehabil, vol. 18, pp. 152-158, 2008.

9. Susan Burt, James A Deddens, Ken Crombie, Yan Jin, Steve Wurzelbacher, Jessica Ramsey, A prospective study of Carpal Tunnel Syndrome: Workplace and Individual Risk factors, BMJ Publishing Group Ltd, 2013.

10. Lusianawaty Tana, dkk., Carpal Tunnel Syndrome pada pekerja garmen di Jakarta, Buletin Penelitian Kesehatan, vol/no: 32(2), pp. 73-82, 2004.

11. Suma'mur, Ergonomi untuk Produktivitas Kerja, Jakarta, CV Aji Mas Agung, 1989.

12. Gradjean E., Fitting The Task To The Man ,4t Ed., Lodon, Taylor and Francis Inc, 1993.

13. Armstrong, Theodore, Risk Factors for Carpal Tunnel Syndrome and Median Neuripathy in a Working Population, Journal of Occupational \& Enviromental Medicine, vol/no: 50(12), pp. 1355-1364, 2008. 
14. Wahyudi W., Hubungan Lama Paparan Getaran dengan Kejadian CTS pada Pekerja Tikar Mendong di Bagian Penjahitan, Tasikmalaya, Fakultas Kesehatan Masyarakat Universitas Siliwangi, 2007.

15. Rogier, M van Rijn, Associations between work-related factors and the carpal tunnel syndrome - a systematic review, Journal of Work, Environment \& Health, vol/no: 35(1), pp. 19-36, 2009. 